\title{
Sedimentary biogeochemical record in Lake Gonghai: implications for recent lake changes in relatively remote areas of China
}

Dejun Wan ${ }^{\mathrm{a}, \mathrm{b}, *}$, Xin $\mathrm{Mao}^{\mathrm{a}}$, Zhangdong Jin ${ }^{\mathrm{b}, \mathrm{c}}$, Lei Song ${ }^{\mathrm{a}}$, Jinsong Yang ${ }^{\mathrm{a}}$, Handong Yang $^{\mathrm{d}, *}$

a Institute of Hydrogeology and Environmental Geology, Chinese Academy of Geological Sciences, Shijiazhuang 050061, China

b State Key Laboratory of Loess and Quaternary Geology, Institute of Earth Environment, Chinese Academy of Sciences, Xi' an 710075, China

${ }^{c}$ Institute of Global Environmental Change, Xi'an Jiaotong University, Xi'an 710049, China

d Environmental Change Research Centre, University College London, London WC1E 6BT, UK 


\section{Abstract}

Owing to rapid social-economic development and climate warming, lakes even in remote areas have experienced marked changes in the last century. However, there are few studies revealing the multi-faceted biogeochemical changes and disentangling impacts of human and climate in relatively remote lakes in China. In this study we reconstructed historical changes of geochemistry, nutrition, primary production, ecology, and pollution in an alpine lake (Gonghai) in central North China, and revealed coherent changes and drivers in relatively remote Chinese lakes by compiling other records. Results show that Lake Gonghai has experienced considerably biogeochemical changes since the 1980s induced mainly by increased regional human activities, with detected human-related changes occurring in the 1950s-1970s. The most important change is a shift of diatom primary producers in the 1980s, caused mainly by an increase of regional atmospheric $\mathrm{N}$ and $\mathrm{P}$ deposition associated with rapid social-economic development. Another remarkable change is the increase of pollution levels since the 1980s, represented by heavy metals, also caused by atmospheric deposition. Compiled sediment records demonstrate similar biogeochemical changes in most lakes from relatively remote areas of China since the 1970s-80s, associated closely with increased inputs of human-induced atmospheric N, $\mathrm{P}$ and pollutants, whereas the influence of climate warming is likely limited. This study highlights markedly human-related biogeochemical changes in relatively remote Chinese lakes during the Anthropocene epoch. 
Keywords: global warming; human activity; pollution; diatom; regime shift; remote lake

\section{Introduction}

Lakes, covering an area of 4.2 million $\mathrm{km}^{2}$ in the world, constitute $~ 90 \%$ of inland water area and $\sim 2.8 \%$ of Earth's land surface area (Downing et al., 2006; O'Beirne et al., 2017). They are widely considered as one of the most important components of terrestrial ecosystem, as they regulate regional climate and maintain biodiversity and regional ecosystem balance and are essential water resources for humans (An et al., 2007; Williamson et al., 2009; Yang and Lu, 2014). As sentinels of environmental change, lakes provide key insights in the effects and mechanisms of climate and human activity (Williamson et al., 2009). In China, many lakes have experienced unprecedented changes, such as shrinking and even disappearance, eutrophication, and pollution in recent decades (An et al., 2007; Ma et al., 2010; Zhou et al., 2017), associated with climate warming and dramatic increase of human activities. Most of the previous studies have concentrated on large lakes from relatively populated areas in eastern and central China, such as Lake Taihu, Lake Chaohu, Lake Poyang, Lake Dongting, and Dian Chi (e.g. An et al., 2007; Huang et al., 2014; Zhou et al., 2017). Certainly, studies on these lakes are of great significance, due to severe environmental problems and their close relation with human beings. However, as these lakes are often heavily affected by local human activities, their changes are only of local implications and thus do not provide information on 
understanding regional aquatic environmental changes.

In contrast, lakes in relatively remote areas are only affected by regional anthropogenic impacts, besides natural forcings, via long-range atmospheric transport and deposition. Hence bio-geochemical changes in these lakes have good regional representativeness and are often considered to be background responses of aquatic ecosystems in a vast region to environmental changes (Brahney et al., 2015; Catalan et al., 2013; Jones et al., 2015), which is helpful in understanding the influence of regional environmental changes on terrestrial ecosystems. In recent years, investigations of relatively remote lakes in the Qinghai-Tibetan Plateau, the Yunnan-Guizhou Plateau, Northeast China indicate that most of them have experienced considerable changes in pollution, eutrophication, and geochemical cycling (e.g. Guan et al., 2012; Gui et al., 2012; Lami et al., 2010; Liu et al., 2013a; Sha et al., 2017; Yuan et al., 2014; Zan et al., 2012; Zhang et al., 2016), though their changes are not as significant as those from densely populated areas (e.g. Chen et al., 2014; Guo et al., 2010; Lami et al., 2010; Liu et al., 2014; Panizzo et al., 2013; Yang et al., 2016). Moreover, some of them have even experienced ecological shifts caused by global warming or increased atmospheric $\mathrm{N}$ and/or $\mathrm{P}$ inputs (Hu et al., 2014; Panizzo et al., 2013). However, previous studies mostly investigated only one- or two-facet changes, such as pollution (Guan et al., 2012; Liu et al., 2013a, 2014; Yang et al., 2016), geochemistry (Liu et al., 2014; Yu et al., 2017), ecology/nutrients (Chen et al., 2014; Hu et al., 2014; Zan et al., 2012; Zhang et al., 2016), which only revealed a portion of the main stressors and lake responses. Therefore, it is necessary to choose 
more representative lakes in China to reveal their multi-faceted biogeochemical changes and drivers in recent decades/centuries in order to comprehensively understand the impact of recent climatic and environmental changes on aquatic ecosystems.

North China is one of the most populated regions and has been heavily affected by recent human activities. However, there are few investigations conducted in this region owing to lack of ideal geological records. Lake Gonghai is one of the few alpine lake in the relatively remote areas of central North China (Fig. S1 and 5). It is a naturally hydrologically-closed watershed and has been minimally impacted by local human activities. Hence it is an ideal lake to investigate natural versus anthropogenic variabilities in an aquatic ecosystem outside the influence of direct human activities. In this study, we employed a multi-proxy approach by measuring five distinct biogeochemical proxies in a more than two-century sediment record from Lake Gonghai and compared the record with others from relatively remote lakes over China. The aims of the study are (1) to investigate multi-faceteded biogeochemical changes of Lake Gonghai, including major element cycling, nutrient status, primary productivity, ecology, and pollution, (2) to identify major drivers of the changes, (3) to disentangle impacts of human activity and climate warming on these changes, and (4) to reveal coherent changes and their drivers in relatively remote lakes over China. This study provides background information on recent biogeochemical changes in Chinese inland lakes under the influence of human activity and climate warming, which is significant for predicting their future trends, sorting out major problems, 
establishing targeted measures to preserve them, and even understanding the impacts of recent climatic and environmental changes on other types of terrestrial ecosystems.

\section{Materials and methods}

\subsection{Site description}

Lake Gonghai $\left(38^{\circ} 55^{\prime} \mathrm{N}, 112^{\circ} 14^{\prime} \mathrm{E}\right)$ is an alpine lake in Shanxi Province, central North China (Fig. S1 and 5). It is situated on the remote Lvliang Mountains in Ningwu County, with an altitude of $~ 1860$ meters above sea level. It is relatively remote to the cities and has experienced limited influence from local human activity (Wan et al., 2016). It is a rare and ideal lake in central North China, one of the most populated regions in China, to reveal past regional anthropogenic impacts on remote aquatic ecosystems. The lake is a freshwater and hydrologically-closed lake, with maximum water depth of about 10 meters. The lake area is $0.21 \mathrm{~km}^{2}$ with a small catchment $\left(\sim 0.5 \mathrm{~km}^{2}\right)$. The climate in this area is dominated by the temperate continental monsoon, exhibiting remarkable seasonality. The annual temperature averages $6.2^{\circ} \mathrm{C}$ and the mean annual precipitation is about $468 \mathrm{~mm}$ in the area, with $\sim 65 \%$ of annual precipitation from June to August (Chen et al., 2013).

\subsection{Sampling and analysis}

A $60-\mathrm{cm}-$ long sediment core was recovered in the deep area of Lake Gonghai using a gravity corer in January 2014. After sectioned at 1.0-cm interval, samples were dried with a vacuum-freezing dryer at $-25{ }^{\circ} \mathrm{C}$ and sub-sampled for grinding to 
fine powder $(<63 \mu \mathrm{m})$ for chemical analysis.

Activities of ${ }^{137} \mathrm{Cs},{ }^{210} \mathrm{~Pb}$, and ${ }^{226} \mathrm{Ra}$ in the sediment samples were detected by a low-background germanium detector (EG and GOrtec Gamma Spectrometry) at the State Key Laboratory of Lake Sciences and Environment. ${ }^{137} \mathrm{Cs}$ and ${ }^{210} \mathrm{~Pb}$ activities were detected at $662 \mathrm{keV}$ and $46.5 \mathrm{keV}$, respectively. ${ }^{226} \mathrm{Ra}$ activities were determined at $295 \mathrm{keV}$ and $352 \mathrm{keV}$ gamma rays emitted by its daughter isotope of ${ }^{214} \mathrm{~Pb}$. Unsupported ${ }^{210} \mathrm{~Pb}\left({ }^{210} \mathrm{~Pb}\right.$ ex $)$ activities were calculated by subtracting ${ }^{226} \mathrm{Ra}$ activities from the total ${ }^{210} \mathrm{~Pb}$ activities and further corrected by supposing equilibrium at deeper than $\sim 40 \mathrm{~cm}$ to remove possible errors. Standard errors $(1 \sigma)$ have been calculated from the counting statistics.

Particle size of the sediment was measured using a Malvern 2000 laser diffraction analyzer. Samples were pretreated with $10 \% \mathrm{H}_{2} \mathrm{O}_{2}$ and $30 \% \mathrm{HCl}$ to remove organic matter and carbonates respectively, and then dispersed by ultrasonication with $10 \mathrm{~mL}$ $10 \%\left(\mathrm{NaPO}_{3}\right)_{6}$ solution. Particle-size measurement range of the analyzer is from 0.02 to $2000 \mu \mathrm{m}$. Replicate analysis indicates that the mean particle size measurement error is less than $2 \%$.

For element determinations, $\sim 0.125 \mathrm{~g}$ of ground sediment sample was weighted and hot-digested with mixed acid of $\mathrm{HNO}_{3}, \mathrm{HClO}_{4}$ and $\mathrm{HCl}$ (Wan et al., 2016). Concentrations of $\mathrm{Al}, \mathrm{Fe}, \mathrm{Ca}, \mathrm{Mg}, \mathrm{Ti}, \mathrm{P}, \mathrm{Sr} \mathrm{V}$, and $\mathrm{Zn}$ in the sediment samples were measured by a Leeman Labs Profile inductively coupled plasma atomic emission spectrometry (ICP-AES) and trace elements including $\mathrm{Rb}, \mathrm{Cr}, \mathrm{Co}, \mathrm{Ni}, \mathrm{Cu}, \mathrm{Tl}, \mathrm{As}, \mathrm{Cd}$, $\mathrm{Sb}, \mathrm{Pb}$, and ${ }^{206} \mathrm{~Pb} /{ }^{207} \mathrm{~Pb}$ ratio by an Agilent $7700 \mathrm{x}$ inductively coupled plasma mass 
spectrometry (ICP-MS). The precision of these measurements is less than $5 \%$ of their two relative standard deviations (2 s.d.).

Total carbon contents of the sediment samples were determined using an elemental analyzer (Elemental Analyzer vario EL III) at the Institute of Earth Environment, Chinese Academy of Sciences. Repetitive errors were less than $3 \%$. Inorganic carbon contents of the sediment samples were measured using a volumetric method. Inorganic carbon contents were converted to carbonate contents by multiplying a coefficient of 8.33 (Wan et al., 2016). Then total organic carbon (TOC) content of each sediment sample was calculated by subtracting inorganic carbon content from the total carbon content.

For diatom analysis, organic and carbonate components in sediment sample were removed by using $30 \% \mathrm{H}_{2} \mathrm{O}_{2}$ and $37 \% \mathrm{HCl}$ and then mounted on microscope slides using high refraction mountant Naphrax (Battarbee et al., 2001). Diatoms were counted using an Olympus BX53 microscope (Olympus Corporation, Tokyo, Japan) with an oil immersion objective at a magnification $10 \times 100$. A minimum of 500 valves were counted for each sample and taxonomy mainly followed Krammer and Lange-Bertalot (1986, 1988, 1991a, 1991b). Only diatom taxa with $\geq 2 \%$ abundance were counted and all numerical calculations were based on abundance percentage.

\section{Results and discussion}

\subsection{Sediment chronologies}

Equilibrium depth of total ${ }^{210} \mathrm{~Pb}$ activity with supported ${ }^{210} \mathrm{~Pb}$ activity is a depth 
of around $29.5 \mathrm{~cm}$ of the core. In general, ${ }^{210} \mathrm{~Pb}_{\mathrm{ex}}$ activities decline more or less following an exponential trend with depth, but with some fluctuations (Fig. S2). For example, there is a considerable dip in ${ }^{210} \mathrm{~Pb}_{\mathrm{ex}}$ activity at $14.5 \mathrm{~cm}$. Cesium-137 activities are relatively high in the top $20.5 \mathrm{~cm}$ of the core (Fig. S2), and then rapidly decline with depth, suggesting that the 1963 depth receiving the fallout maximum from the atmospheric testing of nuclear weapons is very likely to be at $20.5 \mathrm{~cm}$, and the relatively high ${ }^{137} \mathrm{Cs}$ activities in the shallower sediments are likely to be the consequence of catchment input. The core's chronologies were calculated using the constant rate of ${ }^{210} \mathrm{~Pb}$ supply (CRS) model (Appleby, 2001), which placed 1963 depth at $19.5 \mathrm{~cm}$, in reasonable agreement with the ${ }^{137} \mathrm{Cs}$ record. Sedimentation rates in the ${ }^{210} \mathrm{~Pb}$ dated section of the core were calculated using the CRS model, and the rates are relatively uniform. We have extrapolated these rates by using an average of $(0.1576 \mathrm{~g}$ $\left.\mathrm{cm}^{-2} \mathrm{yr}^{-1}\right)$ to provide tentative estimates for the dates before the 1910s of the core. Although there is dating uncertainty in the lower half part of the core, it likely has little influence on drawing major conclusions in this study, considering biogeochemical changes in the lake occurred mainly in the upper core section (1950s-2014).

\subsection{Variations of major elements associated with climate change}

Fig. 1 shows considerable increases in contents of both organic matter and carbonates in the upper part of the core. The increases can significantly dilute element concentrations in the sediment. Hence, in the following, elemental ratios ( $\mathrm{Ti}$ as a 
reference element) (Fig. 1) are employed to discuss recent elemental changes in the lake.

Generally, elemental ratios in a hydrologically-closed lake are controlled by (1) fluxes and element compositions of terrestrial minerals and (2) chemical weathering (Wan et al., 2015). Specifically, ratios of easily mobile elements to conservative lithogenic elements such as $\mathrm{Rb} / \mathrm{Sr}, \mathrm{Ca} / \mathrm{Ti}$, and $\mathrm{Sr} / \mathrm{Ti}$ in lake sediment are usually tied closely to chemical weathering within the catchment (Jin et al., 2015). Results from Lake Gonghai show that $\mathrm{Rb} / \mathrm{Sr}, \mathrm{Ca} / \mathrm{Ti}, \mathrm{Mg} / \mathrm{Ti}$ and $\mathrm{Sr} / \mathrm{Ti}$ ratios varied significantly and displayed similar or mirror trends along the sediment profile, whereas there were limited variations for the other elemental ratios (Fig. 1). This implies that element changes in Lake Gonghai were mainly controlled by chemical weathering in the last two centuries.

From Fig. 1 it can be seen that the changes can be divided into four stages: (1) pre-1880s, the $\mathrm{Rb} / \mathrm{Sr}$ ratios were the highest in the lake sediment profile, while the $\mathrm{Ca} / \mathrm{Ti}$ and $\mathrm{Sr} / \mathrm{Ti}$ were the lowest, suggesting the lowest chemical weathering rate over the record; (2) in the $1880 \mathrm{~s}-1950$, the $\mathrm{Rb} / \mathrm{Sr}$ ratios decreased gradually, whereas the $\mathrm{Ca} / \mathrm{Ti}$ and $\mathrm{Sr} / \mathrm{Ti}$ ratios increased oppositely, indicating a gradually enhanced chemical weathering; (3) in the 1950s-1980s, the $\mathrm{Rb} / \mathrm{Sr}$ ratios were in a relatively uniform value of $\sim 0.48$, while the $\mathrm{Ca} / \mathrm{Ti}$ and $\mathrm{Sr} / \mathrm{Ti}$ ratios came into a trough, implying a weakened chemical weathering process; and (4) in $\sim 1990-2014$, the $\mathrm{Rb} / \mathrm{Sr}$ ratios decreased quickly, while the $\mathrm{Ca} / \mathrm{Ti}$ and $\mathrm{Sr} / \mathrm{Ti}$ ratios increased sharply, indicating acceleratedly enhanced chemical weathering. 
As an undisturbed lake, chemical weathering within the catchment should be controlled dominantly by climate change. Fig. 1 shows that the increase trend of chemical weathering since the 1880 s corresponds roughly to recent global warming (Mann et al., 2008). Moreover, during the 1950s-1980s there was a decline in temperature in China (Zhou and Yu, 2006), and chemical weathering within the lake catchment also weakened, indicated by declines of $\mathrm{Ca} / \mathrm{Ti}$ and $\mathrm{Sr} / \mathrm{Ti}$. Correlation analyses show that the correlation coefficients $\left(\mathrm{R}^{2}\right)$ of the $\mathrm{Rb} / \mathrm{Sr}, \mathrm{Ca} / \mathrm{Ti}$ and $\mathrm{Sr} / \mathrm{Ti}$ are $-0.678,0.351$, and 0.686 with the annual temperature anomalies in the Northern Hemisphere in 1780s-2006 (Mann et al., 2008) and are -0.483, 0.526, and 0.529 with the annual temperatures in Shanxi Province in 1951-2010 (Zhang et al., 2013), respectively. However, the coefficients of $\mathrm{Rb} / \mathrm{Sr}, \mathrm{Ca} / \mathrm{Ti}$ and $\mathrm{Sr} / \mathrm{Ti}$ with the annual rainfall amounts in Xinzhou (Huang et al., 2015) are all <0.01. These correlations suggest that chemical weathering in Lake Gonhai was controlled by temperature rather than rainfall within the last two centuries or so.

\subsection{Variations of nutrient proxies and lake ecology}

\subsubsection{Relation with climate change}

Since 1900 the temperature in China has increased rapidly (Fig. 1) (Zhou and Yu, 2006), but contents of organic matter, TN and TP in the lake sediment profile were relatively stable before $\sim 1950$ (Fig. 2). This indicates that variations of organic matter, TN and TP in Lake Gonghai at the decadal timescale may have little relation with climate change in the last century. In contrast, the obvious increases of organic matter, 
TN and TP since the 1950s (Fig. 2) corresponded well with the rapid social development after the founding of the People's Republic of China in 1949. Although sedimentary TP usually has a considerable degree of post depositional mobility (Boström, 1984), its coherent increase with $\mathrm{P}_{2} \mathrm{O}_{5}$ consumption (Fig. 2), similar to TN with net reactive $\mathrm{N}(\mathrm{Nr})$ creation in China (Fig. 2) as well as $\mathrm{Cd}$ and $\mathrm{Pb}$ with their atmospheric emission amount (Fig. 2 and 6), indicates the TP profile is reflective of atmospheric input. These facts suggest that changes of organic matter, TN and TP in Lake Gonghai were likely to be caused by the influence of human activities rather than climate change.

\subsubsection{Variations during the 1950 s to $\sim 1985$}

From the 1950s to $\sim 1985$, contents of organic matter and TN and TOC/TN in the lake sediment increased gradually. Ranges of TOC/TN for aquatic algae and terrestrial plants (Fig. 3) suggest that these increases are possibly caused by (1) increased flux of terrestrial organic matters, (2) reduced primary productivity in the lake, and/or (3) diagenetic loss over time. Firstly, diagenetic loss of organic matter was likely limited during this period, as indicated by a study that tracked organic matter over 27 years by using annual varves, which found that $\sim 87 \%$ of sedimentary carbon loss occurred within the first five years (Gälman et al., 2008). Secondly, the obvious increase of TOC/TN suggests that the increase of organic matter during this period was caused by increased input of terrestrial organic matter rather than lacustrine, as indicated by different values of TOC/TN for aquatic algae and terrestrial plants (Fig. 3). The minor change of diatom assemblage before $\sim 1985$ (Fig. 2) also indicates a probably stable 
status of the lake's primary productivity.

As a hydrologically-closed lake on the eastern Loess Plateau, sediments of Lake Gonghai are contributed by both catchment erosion and aeolian deposition. The facts of (1) limited human activities around the lake and (2) non-increase trends of annual rainfall and temperature in the 1950s-1980s (Huang et al., 2015; Zhang et al., 2013) suggest that the mechanical erosion within the catchment was likely stable during this period. Hence the increased input of terrestrial organic matters should be caused by an increase in aeolian deposition. Firstly, a study investigated aeolian deposition on the Loess Plateau found that organic matter contents in summer samples accounted for 22.3-42.9\% (Sun et al., 2001) which are 3-5 times higher than that in the sediments of Lake Gonghai. This implies the possibility of aeolian deposition as a contributor of organic matter increase in Lake Gonghai. More importantly, the increase of aeolian input fitted well with changes in dust activities during this period observed at a meteorological station near Lake Gonghai (Ma et al., 2008) (Fig. 2). The increase in aeolian deposition was probably related to rapid social development oriented on agriculture and animal husbandry in inland China, such as large-scale land reclamation, over-grazing and deforestation after the founding of the People's Republic of China in 1949 (Chen and Tang, 2005; Dong et al., 2000; Liu et al., 2015; Wang et al., 2012, 2018). Moreover, the change can also be seen from particle size distributions in the sediment profile, characterized by higher contents of coarse silt and sand during $\sim 1950-1970$ s than before $\sim 1950$ (Fig. 2).

\subsubsection{Variations during $\sim 1985$ to 2014}


From $\sim 1985$ to 2014 , contents of organic matter and TN in the lake sediments continued to increase, but the TOC/TN decreased sharply. Diatom results show a considerable decrease in Cyclotella praetermissa and explosion of two diatom taxa, Cyclotella ocellata and Fragilaria tenera, in 1985 (Fig. 2), suggesting an ecological shift in the lake. It is suggested that ecological shift in lakes is usually related to climate warming and/or elevated nutrient levels (Post et al., 2009; Anderson et al., 2013; Catalan et al., 2013). Meteorological record in Shanxi Province (Fig. 2) shows that the recent warming trend after the 1960-70 "hiatus" began in 1994 (Zhang et al., 2013), which was about ten years later than the diatom shift in Lake Gonghai. Moreover, investigation of diatom changes in tens of relatively natural lakes from North America and Europe suggests that Cyclotella taxa would increase notably if the lakes are primarily affected by climate warming (Rühland et al., 2008). However, our diatom results show a decrease trend of Cyclotella taxa since the 1980s. This fact suggests that the ecological shift in the 1980s in Lake Gonghai was more likely related to anthropogenic drivers of nutrient increase via atmospheric deposition than climate warming, and this is confirmed by marked increases in both TN and TP in the sediments since the 1980s (Fig. 2).

During the period, the ranges of TOC/TN for aquatic algae and terrestrial plants (Fig. 3) indicate that the sharp decrease of TOC/TN was related to increased accumulation of aquatic organic matters in the lake sediment, suggesting an increased primary productivity in the lake. Although TN has increased since the late 1970s, lake's primary productivity did not change until $\sim 1985$. This may be due to that $\mathrm{N}$ 
level did not reach the threshold until $\sim 1985$ and/or P was an important ecological factor in Lake Gonghai. Considering (1) remoteness of the lake and (2) limited impact of recent climate change on $\mathrm{N}$ and $\mathrm{P}$ in the lake, these changes since $\sim 1985$ should be resulted from increased long-range atmospheric transport and deposition of anthropogenic $\mathrm{N}$ and $\mathrm{P}$ (Holtgrieve et al., 2011; Hu et al., 2014; Zhu et al., 2016). Compared with the annual net $\mathrm{Nr}$ creation between 1910-2010 (Cui et al., 2013) and annual $\mathrm{P}_{2} \mathrm{O}_{5}$ consumption in China between 1960-2014 (Gao, 2015), it can be found that increases of $\mathrm{N}$ and $\mathrm{P}$ in Lake Gonghai were concurrent with them (Fig. 2). This further suggests the anthropogenic origin of recent increases in $\mathrm{N}$ and $\mathrm{P}$ in Lake Gonghai.

\subsection{Pollution trends of heavy metals}

Distributions of eleven heavy metals of $\mathrm{V}, \mathrm{Cr}, \mathrm{Co}, \mathrm{Ni}, \mathrm{Cu}, \mathrm{Zn}, \mathrm{Tl}, \mathrm{As}, \mathrm{Cd}, \mathrm{Sb}$ and $\mathrm{Pb}$ in the sediment core are shown in Fig. 4. For $\mathrm{V}, \mathrm{Cr}, \mathrm{Co}, \mathrm{Ni}, \mathrm{Cu}, \mathrm{Zn}$, and $\mathrm{Tl}$, their concentrations likely show a slight decline trend in the upper core section. This was probably caused by natural forcings such as dilution by the increase of organic matter and carbonates in the sediments (Fig. 1), which increased from $11 \%$ to $22 \%$ over the last century. Such changes of these metals were unlikely to be related to anthropogenic pollution, so they are not discussed below.

In contrast, concentrations of $\mathrm{As}, \mathrm{Cd}, \mathrm{Sb}$ and $\mathrm{Pb}$ show marked increases in recent decades. It is suggested that $\mathrm{As}$ and $\mathrm{Sb}$ in the sediment can be easily affected by redox and often have peaks just below the water-sediment interface (Couture et al., 2010). 
Compared with atmospheric heavy metal emission during 1949-2012 in China (Tian et al., 2015), variations of $\mathrm{As}$ and $\mathrm{Sb}$ in the core show totally different patterns, whereas $\mathrm{Pb}$ and $\mathrm{Cd}$ show similar patterns with their emissions (Fig. 4 and 6). This suggests that variations of $\mathrm{As}$ and $\mathrm{Sb}$ were also likely related to natural forcing rather than anthropogenic pollution.

For $\mathrm{Pb}$ and $\mathrm{Cd}$, their concentrations and anthropogenic fluxes are relatively low and stable before $\sim 1980$, but increased quickly since the 1980s, especially in the 1990s (Fig. 4). The ${ }^{206} \mathrm{~Pb} /{ }^{207} \mathrm{~Pb}$ profile shows a decrease trend since the 1980s (Fig. 4), together with similar trends of $\mathrm{Pb}$ and $\mathrm{Cd}$ with their estimated emissions (Fig. 4 and 6), indicating anthropogenic origin for $\mathrm{Pb}$ and probably for $\mathrm{Cd}$ as well. Since the lake is seldom affected directly by human activities, these increases could be derived only from long-range atmospheric transport and deposition (Wan et al., 2016). In fact, this change corresponded well to the rapid socio-economic development period in Shanxi Province (Fig. 4, GIP), as well as in China as a whole, after the Reform and Opening-up in 1978. Since 2001 , both concentrations and fluxes of $\mathrm{Cd}$ and $\mathrm{Pb}$ increased slowly or even decreased slightly compared to those in the 1990s, though the regional economy was still developing quickly. This was likely as a consequence of (1) phasing out of leaded gasoline in 2000 in China (Tian et al., 2015) and (2) implementation of "Atmospheric Pollution Prevention Law" from 2000 dealing with air pollution in China (Hao et al., 2007; Bao and Hu, 2011).

According to the sediment quality guidelines for heavy metals in freshwater ecosystems (MacDonald et al., 2000), only As concentrations (9.3-12.5 $\mathrm{mg} \mathrm{kg}^{-1}$ ) in the 
lake sediment exceed the threshold effect level $\left(5.9 \mathrm{mg} \mathrm{kg}^{-1}\right)$, which is likely due to relatively high background value of $\mathrm{As}\left(10.4 \mathrm{mg} \mathrm{kg}^{-1}\right)$ in the local natural soil (CNEMC, 1990). The concentrations of As are still below the probable effect level (17.0 mg kg-1) (MacDonald et al., 2000), indicating a tolerable/acceptable ecological risk in Lake Gonghai. Concentrations of $\mathrm{Cd}, \mathrm{Sb}$ and $\mathrm{Pb}$ are all below the guideline values, suggesting no ecological risk of these heavy metals in the lake.

3.5. Comparison with other relatively remote lakes in China: coherent changes and possible drivers

\subsubsection{Beginning of the changes}

Biogeochemical records from other fifteen lakes in relatively remote areas of China are compiled and shown in Fig. 5. Most of these records show similar changes to Lake Gonghai (Fig. 5, as well as many others not shown in the figure), characterized by marked changes of most biogeochemical proxies including TN, TP, TOC, TCO/TC (or $\mathrm{C} / \mathrm{N}$ ), $\delta^{13} \mathrm{C}$, diatom, heavy metals, $\mathrm{Pb}$ isotope ratios, and PAHs in recent decades (e.g. Chen et al., 2014; Guan et al., 2012; Gui et al., 2012; Liu et al., 2013a, 2014; Panizzo et al., 2013; Sha et al., 2017; Yang et al., 2016; Zan et al., 2012). Fitting analysis of these records suggests that recent remarkably biogeochemical changes in these lakes began in the 1970s-80s (Fig. 6). The time corresponded approximately to the start of rapid socio-economic development in China after the Reform and Opening-up in 1978, implying a probability of human-induced changes in most of these lakes (Fig. 6). 
However, it should be noted that the change times in some lakes from relatively remote areas of China are a little earlier or later than 1970s-80s (e.g. Guo et al., 2010; Yuan et al., 2014) and some even have experienced limited changes until now (Lami et al., 2010). This may be caused by (1) lakes experienced different extents of human impacts owing to their different remote levels and uneven social-economic development in China, (2) response patterns of ecology varying in different lakes (Randsalu-Wendrup et al., 2016), and (3) dating uncertainties (Yang and Turner, 2013), especially for the sediment records from lakes with low sediment accumulation rates.

\subsubsection{Pollution history}

Most lake sediment records from relatively remote areas of China suggest one of most important changes is accelerated anthropogenic pollutions since the 1970s-80s, represented by heavy metals and PAHs (Fig. 5. Generally, increased pollutants in relatively remote lakes are considered to be dominantly derived from long-range atmospheric transport and deposition related to regional socio-economic development (Liu et al., 2013a, 2014; Panizzo et al., 2013; Wan et al., 2016). Therefore, the coherent changes likely reflect an increasing trend of pollutants in the atmosphere in China since the 1970s-80s.

High-temporal-resolution records from Lake Gonghai in central North China, Lake Xiaolongwan in Northeast China (Panizzo et al., 2013), and Lake Fuxian and Lake Qingshui in Southwest China (Liu et al., 2013a) (Fig. 5) suggest that some metals had stopped increasing or even declined since 2000 , indicating the effectiveness of the atmospheric pollution prevention campaign started in 2000 . 
However, in recent years $\mathrm{Pb}$ seemed to increase again, implying the necessity of a further nation-wide campaign to control it. Although present levels of the investigated pollutants show no or tolerable ecological risks in most of these lakes (e.g. Liu et al., 2013a, 2014; Panizzo et al., 2013) as in Lake Gonghai, they still need to be given attention as their cumulative effects, possible increase trend in future, and the existence of other more toxic pollutants such as $\mathrm{Hg}$.

\subsubsection{Enhanced nutrient levels and primary production}

Another important coherent change is the obvious increases of TOC/organic matter, TN, and TP in most of relatively remote lakes since the 1970s-80s (Fig. 5) (e.g. Chen et al., 2014; Gui et al., 2012; Liu et al., 2013a; Panizzo et al., 2013; Sha et al., 2017; Zan et al., 2012; Zhang et al., 2016). In some lakes (e.g. Lake Qinghai, Lake Lake Wudalianch, Lake Ngoring, Lake Fuxian, and Lake Gonghai), the present TOC levels have even increased by several folds compared to those before 1950 (Fig. 5)

(Gui et al., 2012; Sha et al., 2017; Zan et al., 2012; Zhang et al., 2016). Previous studies suggest that such changes may be related to (1) enhanced primary production caused by nutrient increase (Gui et al., 2012; Sha et al., 2017; Zan et al., 2012) and/or by climate warming (Chen et al., 2014; Panizzo et al., 2013), (2) increased catchment inputs by erosion (Yu et al., 2017), or (3) increased aeolian deposition (Zhang et al., 2016). However, owing to lack of multi-proxy analyses in most records, conclusions on mechanisms were often inferential and preliminary.

Considering representativeness of Lake Gonghai, its multi-proxy records (Fig. 2) imply that these changes in other lakes with similar conditions may be also related to 
increases in regional atmospheric $\mathrm{N}$ and $\mathrm{P}$ deposition. In fact, this is supported by field monitoring and related changes in many relatively remote lakes, including (1) increase in atmospheric $\mathrm{N}$ and $\mathrm{P}$ deposition in China observed by field atmospheric deposition monitoring (Jia et al., 2014; Liu et al., 2013b; Zhu et al., 2016) (2) coherent increases of TN and TP in many relatively remote lakes (e.g. Gui et al., 2012; Sha et al., 2017; Zan et al., 2012; Zhang et al., 2016), and (3) recent TOC increases in most lake (Chen et al., 2014; Gui et al., 2012; Hu et al., 2014; Sha et al., 2017; Zan et al., 2012; Zhang et al., 2016) coincided with TN and TP trends (Fig. 5). Furthermore, another evidence is that these changes in most lakes occurred in the 1970s-80s, whereas the climate did not start to become warming until the 1990s in China after the "hiatus" (Fig. 1, Zhou and Yu, 2006), implying that climate warming is unlikely to be a major driver.

\subsubsection{Chemical weathering}

With respect to catchment weathering, there are few studies investigating its evolution at multi-annual/decadal timescale over the last one or two centuries in China. This may be due to that this change is less important/obvious compared to pollution and eutrophication, which seems to only alter the accumulation of some easily mobile elements such as $\mathrm{Ca}, \mathrm{Mg}$ and $\mathrm{Sr}$. However, in future this process should be given more attention under the global change scenario, as more and more organic and inorganic carbon will be buried into sediment according to the records in Lake Gonghai (Fig. 1) and Lake Qinghai (Sha et al., 2017). For example, in Lake Gonghai inorganic carbon buried in the early 2010 s is $166 \%$ of that before 1880 . 


\subsubsection{Implications of the changes}

Sediment records in Fig. 6 reveal that although these lakes from relatively remote areas of China are experiencing limited direct human impacts, they still have experienced marked biogeochemical changes since the 1970s-80s, mainly caused by increased anthropogenic inputs of nutrients and metals via atmospheric transport and deposition. In contrast, the influence of climate warming on those lakes was likely to be limited. However, there may be exceptions, as key factors causing ecological changes may vary in different lakes, atmospheric $\mathrm{N}$ and $\mathrm{P}$ deposition fluxes are not even over China (Jia et al., 2014; Zhu et al., 2016), and the lakes are in different remote levels. Therefore, more representative lakes need to be investigated to reveal similarities and differences of biogeochemical changes among different regions in China.

Considering the regional representativeness of relatively remote lakes, these coherent changes may represent biogeochemical responses of inland lakes to environmental changes in China. Therefore, the findings imply the need for a greater understanding of the impacts of climate change and human activities on regional aquatic and even other types of ecosystems and defining the Anthropocene in China. Moreover, as remote lakes usually act as habitats for many rare and endangered species and essential water resources, these findings are also of practical significance for making targeted measures of protection.

\subsection{Comparison with relatively remote lakes over the globe}


The facts above suggest that it is increased human activities, rather than climate warming, the have dominated recent geochemical and biological changes in many lakes from relatively remote areas of China. This is similar to many investigations of relatively remote lakes in Europe and North America, even though they usually show an earlier beginning change time than in China (Elser et al., 2001; Hundey et al., 2014; Saros et al., 2011; Sheibley et al., 2014; Sickman et al., 2003; Wolfe et al., 2001). This implies that coherent marked biogeochemical changes is mainly associated with human activities in inland lakes from relatively remote areas over the globe during the Anthropocene. However, there are exceptions. Some investigations suggest that climate warming can be the major drivers for lakes' biogeochemical changes, especially in high-latitude regions (Lehnherr et al., 2018; Post et al., 2009; Rantala et al., 2017). This is likely due to that (1) high-latitude regions have experienced relatively more significant warming compared to temperate regions (IPCC, 2013) and (2) lakes in high-latitude regions are usually more remote and suffer lower levels of human impacts compared to those in temperate regions like China (Rantala et al., 2017).

\section{Conclusions}

Based on reconstructing multi-faceted biogeochemical changes in an alpine lake in the last two centuries and comparing with other fifteen records from relatively remote lakes over China, the following conclusions are obtained.

1. Lake Gonghai has experienced marked changes in geochemistry, nutrient, 
ecology, and pollution since the 1980s.

2. Multi-proxy analyses suggest that these changes were mainly caused by long-range atmospheric transport and deposition of anthropogenic $\mathrm{N}, \mathrm{P}$ and pollutants that can be attributed to rapid social-economic development in China after the Reform and Opening-up in 1978. Impacts of climate warming on the lake seems limited.

3. Compiled sediment records suggest that similar biogeochemical changes occurred in many relatively remote lakes in China as in Lake Gonghai. Fitting analyses of all these records show a beginning time of 1970s-80s for these recent biogeochemical changes, associated mainly with increased inputs of human-induced atmospheric $\mathrm{N}, \mathrm{P}$ and pollutants.

\section{Acknowledgements}

This work was supported by the Basic Research Program of Institute of Hydrogeology and Environmental Geology CAGS [grant numbers SK201503 and SK201404]; and the National Natural Science Foundation of China [grant number 41405123]. We thank Dr. Fei Zhang at Institute of Earth Environment CAS and Dr. Jianfeng Li at Institute of Hydrogeology and Environmental Geology for their assistance in laboratory analyses and graphic plotting, respectively. We also thank two anonymous reviewers for their valuable suggestions.

\section{Declarations of interest: none}




\section{References}

An, S., Li, H., Guan, B., Zhou, C., Wang, Z., Deng, Z., et al., 2007. China's natural wetlands: past problems, current status, and future challenges. AMBIO 36(4), $335-342$.

Anderson, N.J., Dietz, R.D., Engstrom, D.R., 2013. Land-use change, not climate, controls organic carbon burial in lakes. Proceedings of the Royal Society of London B: Biological Sciences 280(1769), doi: org/10.1098/rspb.2013.1278.

Appleby, P.G., 2001. Chronostratigraphic techniques in recent sediments-Tracking environmental change using lake sediments. Springer, Netherlands, 171-203.

Bao, Y.H., Hu, Y.G., 2011. Discussions on improving the "Atmospheric Pollution Prevention Law". Environmental Science and Management 36(2), 29-31 (in Chinese with English abstract).

Battarbee, R.W., Jones, V.J., Flower, R.J., Cameron, N.G., Bennion, H., Carvalho, L., Juggins, S., 2001. Terrestrial, Algal, and Siliceous Indicators-Tracking environmental change using lake sediments. Springer, Netherlands, 155-202.

Boström, B., 1984. Potential mobility of phosphorus in different types of lake sediment. Internationale Revue der gesamten Hydrobiologie und Hydrographie, 69(4), 457-474.

Brahney, J., Ballantyne, A.P., Kociolek, P., Leavitt, P.R., Farmer, G.L., Neff, J.C., 2015. Ecological changes in two contrasting lakes associated with human activity and dust transport in western Wyoming. Limnology and Oceanography 60(2), 678-695.

Catalan, J., Pla-Rabés, S., Wolfe, A.P., Smol, J.P., Rühland, K.M., Anderson, N.J., et 
al., 2013. Global change revealed by palaeolimnological records from remote lakes: a review. Journal of Paleolimnology 49(3), 513-535.

Chen, C., Zhao, L., Zhu, C., Wang, J., Jiang, J., Yang, S., 2014. Response of diatom community in Lugu Lake (Yunnan-Guizhou Plateau, China) to climate change over the past century. Journal of Paleolimnology 51(3), 357-373.

Chen, F., Liu, J., Xu, Q., Li, Y., Chen, J., Wei, H., Liu Q., Wang Z., Cao X., Zhang, S., 2013. Environmental magnetic studies of sediment cores from Gonghai Lake: implications for monsoon evolution in North China during the late glacial and Holocene. Journal of Paleolimnology 49(3), 447-464.

Chen, Y., Tang, H., 2005. Desertification in north China: background, anthropogenic impacts and failures in combating it. Land Degradation \& Development 16(4), $367-376$.

CNEMC (China National Environmental Monitoring Center), 1990. The Background Values of Elements in Chinese Soils. China Environmental Science Press, Beijing (in Chinese).

Couture, R.M., Gobeil, C., Tessier, A., 2010. Arsenic, iron and sulfur co-diagenesis in lake sediments. Geochimica et Cosmochimica Acta 74, 1238-1255.

Cui, S., Shi, Y., Groffman, P.M., Schlesinger, W.H., Zhu, Y., 2013. Centennial-scale analysis of the creation and fate of reactive nitrogen in China (1910-2010). Proceedings of the National Academy of Sciences USA 110(6), 2052-2057.

Dong, Z., Wan, X., Liu, L., 2000. Wind erosion in arid and semiarid China: an overview. Journal of Soil and Water Conservation 55(4), 439-444. 
Downing, J.A., Prairie, Y.T., Cole, J.J., Duarte, C.M., Tranvik, L.J., Striegl, R.G., McDowell, W.H., Kortelainen, P., Caraco, N.F., Melack, J.M., Middelburg, J.J., 2006. The global abundance and size distribution of lakes, ponds, and impoundments. Limnology and Oceanography 51(5), 2388-2397.

Elser, J.J., Andersen, T., Baron, J.S., Bergström, A.K., Jansson, M., Kyle, M., et al., 2009. Shifts in lake N: P stoichiometry and nutrient limitation driven by atmospheric nitrogen deposition. Science 326(5954), 835-837.

Gao, Y., 2015. Development status, trend and innovation of phosphorus chemical industry in China. Phosphate \& Compound Fertilizer 30(12), 1-7 (in Chinese with English abstract).

Gälman, V., Rydberg, J., de-Luna, S. S., Bindler, R., Renberg, I., 2008. Carbon and nitrogen loss rates during aging of lake sediment: changes over 27 years studied in varved lake sediment. Limnology and Oceanography, 53(3), 1076-1082.

Guan, Y.F., Sun, J.L., Ni, H.G., Guo, J.Y., 2012. Sedimentary record of polycyclic aromatic hydrocarbons in a sediment core from a maar lake, Northeast China: evidence in historical atmospheric deposition. Journal of Environmental Monitoring 14(9), 2475-2481.

Gui, Z., Xue, B., Yao, S., Zhang, F., Yi, S., 2012. Catchment erosion and trophic status changes over the past century as recorded in sediments from Wudalianchi Lake, the northernmost volcanic lake in China. Quaternary International 282, 163-170.

Guo, J., Wu, F., Luo, X., Liang, Z., Liao, H., Zhang, R., et al., 2010. Anthropogenic input of polycyclic aromatic hydrocarbons into five lakes in Western China. 
Environmental Pollution 158(6), 2175-2180.

Hao, J., He, K., Duan, L., Li, J., Wang, L., 2007. Air pollution and its control in China. Frontiers of Environmental Science \& Engineering in China 1(2), 129-142.

Holtgrieve, G.W., Schindler, D.E., Hobbs, W.O., Leavitt, P.R., Ward, E.J., Bunting, L., et al., 2011. A coherent signature of anthropogenic nitrogen deposition to remote watersheds of the northern hemisphere. Science 334(6062), 1545-1548.

Hu, Z., Anderson, N. J., Yang, X., McGowan, S., 2014. Catchment-mediated atmospheric nitrogen deposition drives ecological change in two alpine lakes in SE Tibet. Global Change Biology 20(5), 1614-1628.

Huang, C., Wang, X., Yang, H., Li, Y., Wang, Y., Chen, X., Xu, L., 2014. Satellite data regarding the eutrophication response to human activities in the plateau lake Dianchi in China from 1974 to 2009. Science of the Total Environment 485, 1-11.

Huang, X., Song, B., Fan, G., Lan, G., 2015. Analysis of the climatic changes in Xinzhou district in recent 55 Years. Journal of Shanxi Normal University 29(1), 68-73 (in Chinese with English abstract).

Hundey, E.J., Moser, K.A., Longstaffe, F.J., Michelutti, N., Hladyniuk, R., 2014. Recent changes in production in oligotrophic Uinta Mountain lakes, Utah, identified using paleolimnology. Limnology and Oceanography 59(6), 1987-2001.

IPCC, 2013. Climate Change 2013: The Physical Science Basis. Working Group I Contribution to the Fourth Assessment Report of the IPCC. Cambridge University Press, Cambridge, UK.

Jia, Y., Yu, G., He, N., Zhan, X., Fang, H., Sheng, W., Zuo, Y., Zhang, D., Wang, Q., 
2014. Spatial and decadal variations in inorganic nitrogen wet deposition in China induced by human activity. Scientific Reports 4, 3763, doi:10.1038/srep03763.

Jin, Z., An, Z., Yu, J., Li, F., Zhang, F., 2015. Lake Qinghai sediment geochemistry linked to hydroclimate variability since the last glacial. Quaternary Science Reviews 122, 63-73.

Jones, V.J., Rose, N.L., Self, A.E., Solovieva, N., Yang, H., 2015. Evidence of global pollution and recent environmental change in Kamchatka, Russia. Global and Planetary Change 134, 82-90.

Krammer, K., Lange-Bertalot, H., 1986, 1988, 1991a, and 1991b. Bacillariophyceae (1-4), Süsswasserflora von Mitteleuropa, Band 1-4. Gustav Fischer Verlag, Jena, Germany.

Lami, A., Turner, S., Musazzi, S., Gerli, S., Guilizzoni, P., Rose, N.L., Yang, H., Wu, G., Yang, R., 2010. Sedimentary evidence for recent increases in production in Tibetan plateau lakes. Hydrobiologia 648(1), 175-187.

Lehnherr, I., Louis, V.L.S., Sharp, M., Gardner, A.S., Smol, J.P., Schiff, S.L., et al., 2018. The world's largest High Arctic lake responds rapidly to climate warming. Nature Communications 9, 1290, doi: 10.1038/s41467-018-03685-z.

Liu, D., Abuduwaili, J., Wang, L., 2015. Salt dust storm in the Ebinur Lake region: its 50-year dynamic changes and response to climate changes and human activities. Natural Hazards 77(2), 1069-1080.

Liu, E., Zhang, E., Li, K., Nath, B., Li, Y., Shen, J., 2013a. Historical reconstruction of atmospheric lead pollution in central Yunnan province, southwest China: an 
analysis based on lacustrine sedimentary records. Environmental Science and Pollution Research 20(12), 8739-8750.

Liu, W., Wu, J., Ma, L., Zeng, H., 2014. A 200-year sediment record of environmental change from Lake Sayram, Tianshan Mountains in China. GFF 136(4), 548-555.

Liu, X., Zhang, Y., Han, W., Tang, A., Shen, J., Cui, Z., et al., 2013b. Enhanced nitrogen deposition over China. Nature 494(7438), 459-462.

Ma, R., Duan, H., Hu, C., Feng, X., Li, A., Ju, W., et al., 2010. A half-century of changes in China's lakes: Global warming or human influence? Geophysical Research Letters 37(24), doi: org/10.1029/2010GL045514.

Ma, Z., Bai, X., Yang, S., Xi, Y., Jiang, Y., Hao, X., Zhang, C., 2008. Spatial and temporal distributions of dust storm during the last 50 years in Xinzhou city and its controlling measures. Journal of Anhui Agricultural Sciences 36(4), 1505-1507 (in Chinese).

MacDonald, D.D., Ingersoll, C.G., Berger, T.A., 2000. Development and evaluation of consensus-based sediment quality guidelines for freshwater ecosystems. Archives of Environmental Contamination and Toxicology 39(1), 20-31.

Mann, M.E., Zhang, Z., Hughes, M.K., Bradley, R.S., Miller, S.K., Rutherford, S., Ni, F., 2008. Proxy-based reconstructions of hemispheric and global surface temperature variations over the past two millennia. Proceedings of the National Academy of Sciences USA 105(36), 13252-13257.

Meyers, P.A., Teranes, J., 2001. Physical and Geochemical Methods-Tracking environmental change using lake sediments. Springer, Netherlands, 239-270. 
O’Beirne, M.D., Werne, J.P., Hecky, R.E., Johnson, T.C., Katsev, S., Reavie, E.D., 2017. Anthropogenic climate change has altered primary productivity in Lake Superior. Nature Communications 8, 15713, doi: 10.1038/ncomms15713.

Panizzo, V.N., Mackay, A.W., Rose, N.L., Rioual, P., Leng, M.J., 2013. Recent palaeolimnological change recorded in Lake Xiaolongwan, northeast China: climatic versus anthropogenic forcing. Quaternary International 290, 322-334.

Post, E., Forchhammer, M.C., Bret-Harte, M.S., Callaghan, T.V., Christensen, T.R., Elberling, B., et al., 2009. Ecological dynamics across the Arctic associated with recent climate change. Science 325(5946), 1355-1358.

Randsalu-Wendrup, L., Conley, D. J., Carstensen, J., Fritz, S.C., 2016. Paleolimnological records of regime shifts in lakes in response to climate change and anthropogenic activities. Journal of Paleolimnology 56(1), 1-14.

Rantala, M.V., Luoto, T.P., Weckström, J., Rautio, M., Nevalainen, L., 2017. Climate drivers of diatom distribution in shallow subarctic lakes. Freshwater Biology 62(12), 1971-1985.

Rühland, K., Paterson, A.M., Smol, J.P., 2008. Hemispheric-scale patterns of climaterelated shifts in planktonic diatoms from North American and European lakes. Global Change Biology 14(11), 2740-2754.

Saros, J.E., Clow, D.W., Blett, T., Wolfe, A.P., 2011. Critical nitrogen deposition loads in high-elevation lakes of the western US inferred from paleolimnological records. Water, Air, \& Soil Pollution 216(1-4), 193-202.

Sha, Z., Wang, Q., Wang, J., Du, J., Hu, J., Ma, Y., et al., 2017. Regional 
environmental change and human activity over the past hundred years recorded in the sedimentary record of Lake Qinghai, China. Environmental Science \& Pollution Research International 24(10), 1-13.

Sheibley, R.W., Enache, M., Swarzenski, P.W., Moran, P.W., Foreman, J.R., 2014. Nitrogen deposition effects on diatom communities in lakes from three national parks in Washington State. Water, Air, \& Soil Pollution 225(2), 1857, doi: 10.1007/s11270-013-1857-x.

Sickman, J.O., Melack, J.M., Clow, D.W., 2003. Evidence for nutrient enrichment of high-elevation lakes in the Sierra Nevada, California. Limnology and Oceanography 48(5), 1885-1892.

Sun D., Su R., Chen F., Yuan B., 2001. Composition susceptibility and input flux of present aeolian dust over Loess Plateau of China. Acta Geographica Sinica (2), 171-180 (in Chinese with English abstract).

Tian, H., Zhu, C., Gao, J., Cheng, K., Hao, J., Wang, K., Hua, S., Wang, Y., Zhou, J., 2015. Quantitative assessment of atmospheric emissions of toxic heavy metals from anthropogenic sources in China: historical trend, spatial distribution, uncertainties, and control policies. Atmospheric Chemistry and Physics 15(17), 10127-10147.

Wan, D., Jin, Z., Zhang, F., Chen, H., Chen, L., Song, L., Song, C., 2015. Further quantifying the fluxes and contributions of sources to modern sediment in Lake Qinghai, NE Tibetan Plateau. Limnology 16(1), 11-20.

Wan, D., Song, L., Yang, J., Jin, Z., Zhan, C., Mao, X., Liu, D., Shao, Y., 2016. Increasing heavy metals in the background atmosphere of central North China since 
the 1980s: evidence from a 200-year lake sediment record. Atmospheric Environment 138, 183-190.

Wang, G., Wang, X., Wu, B., Lu, Q., 2012. Desertification and its mitigation strategy in China. Journal of Resources and Ecology 3(2), 97-104.

Wang, X., Liu, J., Che, H., Ji, F., Liu, J., 2018. Spatial and temporal evolution of natural and anthropogenic dust events over northern China. Scientific Reports 8(1), 2141, doi :10.1038/s41598-018-20382-5.

Willianson, C.E., Saros, J.E., Schindler, D.W., 2009. Sentinels of change. Science 323, $887-888$.

Wolfe, A.P., Baron, J.S., Cornett, R.J., 2001. Anthropogenic nitrogen deposition induces rapid ecological changes in alpine lakes of the Colorado Front Range (USA). Journal of Paleolimnology 25(1), 1-7.

Yang, H., Turner, S., 2013. Radiometric dating for recent lake sediments on the Tibetan Plateau. Hydrobiologia 713, 73-86.

Yang, R., Xie, T., Li, A., Yang, H., Turner, S., Wu, G., Jing, C., 2016. Sedimentary records of polycyclic aromatic hydrocarbons (PAHs) in remote lakes across the Tibetan Plateau. Environmental Pollution 214, 1-7.

Yang, X., Lu, X., 2014. Drastic change in China's lakes and reservoirs over the past decades. Scientific Reports 4, 6041, doi: 10.1038/srep06041.

Yu, K., Xu, H., Lan, J., Sheng, E., Liu, B., Wu, H., Tan, L., Yeager, K. M., 2017. Climate change and soil erosion in a small alpine lake basin on the Loess Plateau, China. Earth Surface Processes and Landforms 42(8), 1238-1247. 
Yuan, H., Liu, E., Shen, J., Zhou, H., Geng, Q., An, S., 2014. Characteristics and origins of heavy metals in sediments from Ximen Co Lake during summer monsoon season, a deep lake on the eastern Tibetan Plateau. Journal of Geochemical Exploration 136(11), 76-83.

Zan, F., Huo, S., Xi, B., Zhang, J., Liao, H., Wang, Y., Yeager, K.M., 2012. A 60-year sedimentary record of natural and anthropogenic impacts on Lake Chenghai, China. Journal of Environmental Sciences 24(4), 602-609.

Zhang, H., Lei, P., Shan, B., Tang, W., Ao, L., 2016. Aeolian input of phosphorus to a remote lake induced increase of primary production at the Tibetan Plateau. RSC Advances 6(99), 96853-96860.

Zhang, L., Yan, J., Liu, L., 2013. Climate change and drought and flood disasters trend in Shanxi. Journal of Arid Land Resources and Environment 27(5), 120-125 (in Chinese with English abstract).

Zhou, T., Yu, R., 2006. Twentieth-century surface air temperature over china and the globe simulated by coupled climate models. Journal of Climate 19(22), 5843-5858.

Zhou, Y., Ma, J., Zhang, Y., Qin, B., Jeppesen, E., Shi, K., et al., 2017. Improving water quality in China: Environmental investment pays dividends. Water Research $118,152-159$.

Zhu, J., Wang, Q., He, N., Smith, M. D., Elser, J.J., Du, J., Yuan, G., Yu, G., Yu, Q., 2016. Imbalanced atmospheric nitrogen and phosphorus depositions in China: Implications for nutrient limitation. Journal of Geophysical Research: Biogeosciences 121(6), 1605-1616. 